Original Research Article

\title{
Study of effect of propranolol, atenolol and celiprolol on exercise induced changes in heart rate, blood pressure and peak expiratory flow rate in healthy human volunteers
}

\author{
Sumit P. Patel ${ }^{1}$, Rima B. Shah ${ }^{2 *}$
}

${ }^{1}$ Department of Pharmacology, GCS Medical College, Hospital and Research Centre,

Ahmedabad, Gujarat, India

${ }^{2}$ Department of Pharmacology,

GMERS Medical College,

Gandhinagar, Gujarat, India

Received: 15 February 2019

Revised: 23 March 2019

Accepted: 03 April 2019

*Correspondence to:

Dr. Rima B. Shah,

Email: dr.rimashah@gmail.com

Copyright: (C) the author(s), publisher and licensee Medip Academy. This is an openaccess article distributed under the terms of the Creative Commons Attribution NonCommercial License, which permits unrestricted noncommercial use, distribution, and reproduction in any medium, provided the original work is properly cited.

\begin{abstract}
Background: Beta blockers are known to cause attenuation of sympathetic stimulation mediated increase in cardiovascular parameters. Very few studies are available in Indian set-up comparing these changes between different beta blockers available in market. The objective of the study was to compare efficacy and safety of propranolol, atenolol and celiprolol on heart rare, blood pressure and airway resistance, both at rest and during exercise.

Methods: A prospective interventional study was carried out involving 72 healthy volunteers in the clinical pharmacology laboratory. Participants were divided in three groups of 24 each and given single oral doses of propranolol 40 $\mathrm{mg}$, Atenolol $50 \mathrm{mg}$ and celiprolol $40 \mathrm{mg}$ was given to the participants. Exercise given in the form of step ladder test and hand grip dynamometer and effect on the different parameters like HR, SBP, DBP and PEFR were recorded before and immediately after exercise and compared.

Results: All the three drugs were effective in attenuating the exercise induced cardiovascular parameters ( $\mathrm{p}<0.05$ ). Drug A cause change in HR, SBP, DBP and PEFR significantly $(\mathrm{p}<0.05)$. Change in SBP was more significant with drug B while significant difference was found in HR, SBP and DBP before and after exercise in drug $\mathrm{C}$ in both SL and HGD tests. No significant difference was found between the drug groups ( $p>0.05$ ). No adverse effects were reported in the study participants.

Conclusions: All the three drugs are effective in attenuating cardiovascular changes after sympathetic stimulation like exercise and there was no significant difference among them.
\end{abstract}

Keywords: Atenolol, Celiprolol, Hand grip dynamometer, Propranolol, Step ladder test

\section{INTRODUCTION}

The autonomic nervous system (ANS) maintains homeostasis through the concerted action of its sympathetic and parasympathetic branches. Sympathetic division of ANS acts on pathways mediated by the endogenous catecholamine like norepinephrine, epinephrine, and dopamine etc. These neurotransmitters modulate many vital functions, including the rate and force of cardiac contraction, the resistance of blood vessels and bronchioles, the release of insulin, and the breakdown of fat. ${ }^{1}$ Adrenergic receptors are membrane bound G-protein coupled receptors and has been classified by Ahlquist (in 1948) into two classes $\alpha$ and $\beta$, each comprising three further subclasses $(\alpha 1 \mathrm{~A}, \alpha 1 \mathrm{~B}, \alpha 1 \mathrm{D}$ and $\alpha 2 \mathrm{~A}, \alpha 2 \mathrm{~B}, \alpha 2 \mathrm{C})$ and three $\beta$-receptor subtypes $(\beta 1, \beta 2$ and $\beta 3) .^{2}$ Both adrenoceptors mediate the responses of the cardiovascular system to catecholamine.

Among the $\beta$ receptors, $\beta 1$ receptors are predominantly present in heart and kidney while $\beta 2$ receptors are present in smooth muscles, liver and skeletal muscles and $\beta 3$ receptors are present only in adipose tissue. ${ }^{3}$ 
Drugs that target the postsynaptic receptors are frequent therapies for hypertension, heart failure, primary treatment of myocardial infarction (MI), and secondary prevention of ischemic cardiac events. ${ }^{4}$ As antihypertensive agents, $\beta$ blockers are recommended as initial agents in patients with ischemic heart disease or heart failure and are suggested as an add-on treatment with other antihypertensive agents in a variety of clinical situations. ${ }^{5}$ Initially only non-selective agents were available which limits their use because of adverse effects and contraindications, i.e. bronchial asthma.

Later more potent and selective $\beta 1$ antagonists were introduced with cardioselectivity which increased their safety. $^{2}$ The effects produced by $\beta$ blocker in humans depend on the degree of sympathetic activity and are minimal in subjects at rest. $^{6}$ In a subject at rest, propranolol, a non-selective $\beta$ blocker, causes little change in heart rate, cardiac output or blood pressure, but reduces the effect of exercise or excitement on these variables. It is observed that maximum exercise tolerance is considerably reduced in normal subjects, partly because of the limitation of the cardiac response, and partly because the $\beta$-mediated vasodilatation in skeletal muscle is less. ${ }^{6}$

Clinically, however, it may be more important to compare unwanted side effects such as bronchoconstriction when desirable cardiac effects are similar. It is suggested that newer $\beta 1$ selective blockers have less chances of bronchoconstriction and are safe for use in cardiac patients with concurrent respiratory diseases like asthma. ${ }^{2}$ A study done by Benson MK et el, suggested that cardioselective $\beta$-blockers, given as a single dose or for longer duration, produced no change in forced expiratory volume in 1 second (FEV1) or respiratory symptoms compared to placebo. $^{7}$ Another study showed that $\beta 1$ selective agents like Atenolol have little effect on bronchial muscles and thus are relatively safe in hypertensive patients with bronchial asthma. $^{8}$

But there is very less data available which compares newer $\beta$ blocker agents like atenolol and celiprolol with older ones like Propranolol on healthy human subjects. This study was therefore taken up to address those unsolved issues and compare the efficacy and safety of Propranolol, a non-selective $\beta$ blocker and $\beta 1$ selective blockers i.e. atenolol and celiprolol on heart rare, blood pressure and airway resistance, both at rest and during exercise in healthy volunteers.

\section{Aims and objectives}

- To study and compare effects of Propranolol, atenolol and celiprolol on exercise induced increase in heart rate and blood pressure in healthy volunteers.

- To study and compare the effects of propranolol, atenolol and celiprolol on peak expiratory flow rate.

- To identify, report and analyze the adverse events occurring in the study; if any.

\section{METHODS}

The study was prospective and interventional in nature. It was conducted in clinical CVS laboratory, Department of Pharmacology of tertiary care teaching hospital after approval from the Institutional ethics committee.

\section{Subjects}

Total 72 healthy volunteers participated in the study after explained the general aim of the study and the risk of possible untoward side effects clearly in the language they understand. Participants who gave their written informed consent included in the study. Brief medical history and a complete physical examination of each participant was done before inclusion in the study to declare them as healthy. No cost was borne by the volunteers including that of medicines, tests of the study as well as of any cost involved for treatment of any side effects, if any. Any volunteer participating in the study had freedom to opt out of study without assigning any reason for doing the same.

\section{Drugs}

Single oral doses of Propranolol $40 \mathrm{mg}$ (Abotte, drug A), Atenolol 50 mg(Cadila Pharma, drug B) and Celiprolol 40 mg (Ranbaxy, drug C)was given to the participants.

\section{Experimental design}

A randomized double blind, parallel group study was carried out in the clinical CVS laboratory. Participants were divided randomly into three groups of eight participants in each. Randomization was carried out by computer generated random number table. On the study day, participants were asked to have breakfast at 8 a.m. and report to laboratory at 9 a.m. After 15 minutes of acclimatization period, the baseline heart rate, blood pressure and peak expiratory flow rate (PEFR) was recorded.

Each of the subjects was undergone two standardized exercise tests namely step ladder test (SL) and hand grip dynamometer (HGD), following which the parameters were recorded immediately. Before each period of exercise, the subjects rest for $5 \mathrm{~min}$ and their resting heart rate (HR) and blood pressure was noted. Resting peak flow rate (PFR) (mean of three readings) was determined using a wright peak flow meter. After that the test drug was given along with a glass of water as single dose and then after 90 minutes of resting period both the tests were repeated again, and the parameters was recorded.

Participants were not allowed to eat any food during study time, however drinking water was allowed. Participants were instructed to refrain from smoking, drinking alcohol or taking any medication one week prior and during the study period. The results obtained after each treatment was expressed as differences from the pre-treatment values 


\section{Inclusion criteria}

Healthy human volunteer of age 8-50 years

\section{Exclusion criteria}

- Patients with H/O hypertension, asthma, diabetes mellitus, heart block, peripheral vascular diseases, hyperlipidemia, prinzmetal angina etc.

- Patient on any medication affecting cardio respiratory function.

- Persons having H/O alcohol or any substance abuse.

- Pregnant or lactating woman

\section{Each of the subjects was undergone two standardized exercise tests}

- Step ladder test (SL test): After noting resting baseline data of HR, BP and PEFR, the subject will do stepping on and off a box for 3 minutes. The heart rate and blood pressure and PEFR was recorded immediately after exercise. ${ }^{9}$

- Hand grip dynamometer (HGD test): After noting resting baseline data, the subjects was asked to exert maximum effort on hand grip dynamometer, then he was asked to maintain $25 \%$ of maximum effort on hand grip dynamometer for 90 seconds, the cuff is inflated at 70 seconds and the BP and $\mathrm{HR}$ at 90 seconds are noted down, by volunteer is still performing exercise with the other hand. ${ }^{9}$

\section{Statistical analysis}

Results were recorded as actual frequencies, percentage, mean and standard deviation. Paired t test was used for within group comparison and unpaired t test was used for between group comparisons. $\mathrm{P}$ value less than 0.05 was considered significant.

\section{RESULTS}

Total 24 healthy volunteers were included in each group for the study. There were no significant side-effects observed among all three drugs.

The effects of propranolol, Atenolol and celiprolol on exercise induced heart rate; blood pressure and PEFR are shown in Table 1, Table 2 and Table 3 respectively.

Table 1: Effects of propranolol on exercise induced changes in heart rate, blood pressure and PEFR in healthy volunteers.

\begin{tabular}{|c|c|c|c|c|c|c|c|}
\hline & & \multicolumn{3}{|c|}{ SL test (Drug A) } & \multicolumn{3}{|c|}{ HGD test (Drug A) } \\
\hline & & $\begin{array}{l}\text { Before drug } \\
(\text { Mean } \pm \text { SD) }\end{array}$ & $\begin{array}{l}\text { After drug } \\
(\text { Mean } \pm \text { SD) }\end{array}$ & $\begin{array}{l}P \text { value } \\
\text { (paired } t \\
\text { test) }\end{array}$ & $\begin{array}{l}\text { Before drug } \\
(\text { Mean } \pm \text { SD) }\end{array}$ & $\begin{array}{l}\text { After drug } \\
\text { (Mean } \pm \text { SD) }\end{array}$ & $\begin{array}{l}\text { P value } \\
\text { (paired t } \\
\text { test) }\end{array}$ \\
\hline \multirow{2}{*}{$\begin{array}{l}\text { Mean heart } \\
\text { rate } \\
\text { (beats/min) }\end{array}$} & $\begin{array}{l}\text { Before } \\
\text { Exercise }\end{array}$ & $80.5 \pm 9.78$ & $71.5 \pm 7.46$ & $<0.0001$ & $85 \pm 5.32$ & $70 \pm 3.70$ & $<0.0001$ \\
\hline & After exercise & $135.75 \pm 11.02$ & $99 \pm 4.14$ & 0.130 & $92 \pm 6.23$ & $75.75 \pm 4.30$ & 0.01 \\
\hline \multirow{2}{*}{$\begin{array}{l}\text { Mean } \\
\text { Systolic B.P. } \\
(\mathrm{mmHg})\end{array}$} & $\begin{array}{l}\text { Before } \\
\text { Exercise }\end{array}$ & $115.75 \pm 6.62$ & $112 \pm 7.41$ & $<0.0001$ & $113.5 \pm 4.63$ & $104.5 \pm 5.21$ & 0.07 \\
\hline & After exercise & $158 \pm 14.70$ & $121.25 \pm 6.92$ & 0.045 & $119.5 \pm 8.47$ & $109.25 \pm 3.99$ & 0.06 \\
\hline \multirow{2}{*}{$\begin{array}{l}\text { Mean } \\
\text { Diastolic B.P. } \\
(\mathrm{mmHg})\end{array}$} & $\begin{array}{l}\text { Before } \\
\text { Exercise }\end{array}$ & $77.5 \pm 3.81$ & $74.75 \pm 6.67$ & 0.676 & $75 \pm 4.54$ & $67.5 \pm 6.74$ & 0.164 \\
\hline & After exercise & $78.5 \pm 5.42$ & $77 \pm 7.70$ & 0.149 & $79.75 \pm 5.18$ & $70 \pm 6.23$ & 0.454 \\
\hline \multirow{2}{*}{ Mean PEFR } & $\begin{array}{l}\text { Before } \\
\text { Exercise }\end{array}$ & $472.5 \pm 65.85$ & $483.75 \pm 66.32$ & 0.684 & $476.25 \pm 69.48$ & $463.75 \pm 65.23$ & 0.754 \\
\hline & After exercise & $485 \pm 53.72$ & $489.38 \pm 67.95$ & 0.944 & $465 \pm 40$ & $462.5 \pm 60.65$ & 0.969 \\
\hline
\end{tabular}

SBP =systolic Blood pressure, DBP = diastolic blood pressure, PEFR = peak expiratory flow rate

As shown in Table 1, there was significant difference ( $p$ $<0.001$ ) found between mean heart rate before and after drug A (Propranolol) before exercise in both the test (SL test ad HGD test). There was significance of difference ( $p$ $<0.05$ ) found in HGD test between mean heart rate, also between mean systolic blood pressure before and after propranolol after exercise in SL test. Also there was no significant difference $(p>0.05)$ found between mean PEFR and also between mean diastolic pressure before and after drug before exercise in both the tests (SL test and HGD test) and also there was no significance of difference ( $p$ $>0.05$ ) found between mean PEFR and also between mean diastolic pressure before and after drug after exercise.

As shown in Table 2, there was significant difference ( $\mathrm{p}$ $<0.001)$ found between mean heart rate and also between mean systolic blood pressure before and after drug B (atenolol) before exercise in SL test while there was no 
significance of difference $(\mathrm{p}<0.05)$ found in both the tests between mean heart rate, between mean systolic blood pressure, between mean diastolic blood pressure and mean PEFR before and after drug after exercise.

Table 2: Effects of atenolol on exercise induced changes in heart rate, blood pressure and PEFR in healthy volunteers.

\begin{tabular}{|c|c|c|c|c|c|c|c|}
\hline & & \multicolumn{3}{|c|}{ SL test (Drug B) } & \multicolumn{3}{|c|}{ HGD test (Drug B) } \\
\hline & & $\begin{array}{l}\text { Before drug } \\
(\text { Mean } \pm \text { SD) }\end{array}$ & $\begin{array}{l}\text { After drug } \\
(\text { Mean } \pm \text { SD) }\end{array}$ & $\begin{array}{l}\text { P value } \\
\text { (paired } \\
\text { t test) }\end{array}$ & $\begin{array}{l}\text { Before drug } \\
\text { (Mean士SD) }\end{array}$ & $\begin{array}{l}\text { After drug } \\
(\text { Mean } \pm \text { SD) }\end{array}$ & $\begin{array}{l}\text { P value } \\
\text { (paired } t \\
\text { test) }\end{array}$ \\
\hline \multirow{2}{*}{$\begin{array}{l}\text { Mean heart } \\
\text { rate } \\
\text { (beats/min) }\end{array}$} & $\begin{array}{l}\text { Before } \\
\text { Exercise }\end{array}$ & $87.13 \pm 12.10$ & $74.25 \pm 10.66$ & $<0.0001$ & $90.63 \pm 11.30$ & $72.25 \pm 10.90$ & 0.113 \\
\hline & $\begin{array}{l}\text { After } \\
\text { exercise }\end{array}$ & $140 \pm 16.53$ & $102.63 \pm 17.88$ & 0.286 & $95.25 \pm 10.58$ & $77 \pm 10.36$ & 0.385 \\
\hline \multirow{2}{*}{$\begin{array}{l}\text { Mean Systolic } \\
\text { B.P. (mmHg) }\end{array}$} & $\begin{array}{l}\text { Before } \\
\text { Exercise }\end{array}$ & $122.25 \pm 7.13$ & $116.25 \pm 9.10$ & $<0.0001$ & $120.5 \pm 7.80$ & $114.5 \pm 7.31$ & 0.317 \\
\hline & $\begin{array}{l}\text { After } \\
\text { exercise }\end{array}$ & $168 \pm 15.69$ & $126.25 \pm 15.32$ & 0.386 & $124 \pm 7.71$ & $118 \pm 8.75$ & 0.400 \\
\hline \multirow{2}{*}{$\begin{array}{l}\text { Mean } \\
\text { Diastolic B.P. } \\
(\mathrm{mmHg})\end{array}$} & $\begin{array}{l}\text { Before } \\
\text { Exercise }\end{array}$ & $79.75 \pm 5.18$ & $75.5 \pm 2.10$ & 0.192 & $78.75 \pm 8.21$ & $75.25 \pm 7.40$ & 0.212 \\
\hline & $\begin{array}{l}\text { After } \\
\text { exercise }\end{array}$ & $84.5 \pm 8.33$ & $77.25 \pm 4.90$ & 0.819 & $81 \pm 7.33$ & $78.5 \pm 8.54$ & 0.429 \\
\hline \multirow{2}{*}{ Mean PEFR } & $\begin{array}{l}\text { Before } \\
\text { Exercise }\end{array}$ & $510 \pm 72.90$ & $530 \pm 64.14$ & 0.616 & $515 \pm 82.30$ & $510 \pm 73.48$ & 0.922 \\
\hline & $\begin{array}{l}\text { After } \\
\text { exercise }\end{array}$ & $529 \pm 75.43$ & $525 \pm 72.31$ & 0.945 & $503.75 \pm 73.67$ & $503.75 \pm 78.54$ & 0.872 \\
\hline
\end{tabular}

Table 2: Effects of celiprolol on exercise induced changes in heart rate, blood pressure and PEFR in healthy volunteers.

\begin{tabular}{|c|c|c|c|c|c|c|c|}
\hline & & \multicolumn{3}{|c|}{ SL test (Drug C) } & \multicolumn{3}{|c|}{ HGD test (Drug C) } \\
\hline & & $\begin{array}{l}\text { Before drug } \\
(\text { Mean } \pm \text { SD) }\end{array}$ & $\begin{array}{l}\text { After drug } \\
\text { (Mean+SD) }\end{array}$ & $\begin{array}{l}\text { P value } \\
\text { (paired } t \\
\text { test) }\end{array}$ & $\begin{array}{l}\text { Before drug } \\
(\text { Mean } \pm \text { SD) }\end{array}$ & $\begin{array}{l}\text { After drug } \\
(\text { Mean } \pm \text { SD) }\end{array}$ & $\begin{array}{l}\text { P value } \\
\text { (paired } t \\
\text { test) }\end{array}$ \\
\hline \multirow{2}{*}{$\begin{array}{l}\text { Mean heart } \\
\text { rate } \\
\text { (beats/mim) }\end{array}$} & $\begin{array}{l}\text { Before } \\
\text { Exercise }\end{array}$ & $82.25 \pm 8.75$ & $80.75 \pm 10.74$ & $<0.0001$ & $83.38 \pm 5.58$ & $77.38 \pm 5.87$ & 0.018 \\
\hline & $\begin{array}{l}\text { After } \\
\text { exercise }\end{array}$ & $141.25 \pm 14.01$ & $127.5 \pm 14.05$ & 0.103 & $90 \pm 7.46$ & $85 \pm 10.36$ & 0.092 \\
\hline \multirow{2}{*}{$\begin{array}{l}\text { Mean Systolic } \\
\text { B.P. (mmHg) }\end{array}$} & $\begin{array}{l}\text { Before } \\
\text { Exercise }\end{array}$ & $124.25 \pm 6.80$ & $119 \pm 5.24$ & $<0.0001$ & $119.75 \pm 5.80$ & $111.25 \pm 6.32$ & 0.105 \\
\hline & $\begin{array}{l}\text { After } \\
\text { exercise }\end{array}$ & $169.75 \pm 14.83$ & $136.75 \pm 12.78$ & 0.362 & $124.25 \pm 7.68$ & $114 \pm 4.27$ & 0.325 \\
\hline \multirow{2}{*}{$\begin{array}{l}\text { Mean } \\
\text { Diastolic B.P. } \\
(\mathrm{mmHg})\end{array}$} & $\begin{array}{l}\text { Before } \\
\text { Exercise }\end{array}$ & $83 \pm 4.40$ & $76.5 \pm 5.42$ & 0.724 & $78.25 \pm 6.94$ & $74.25 \pm 6.45$ & 0.053 \\
\hline & $\begin{array}{l}\text { After } \\
\text { exercise }\end{array}$ & $84 \pm 6.50$ & $79.25 \pm 9.91$ & 0.621 & $82.5 \pm 6.11$ & $75.75 \pm 4.20$ & 0.590 \\
\hline \multirow{2}{*}{ Mean PEFR } & $\begin{array}{l}\text { Before } \\
\text { Exercise }\end{array}$ & $502.5 \pm 73.82$ & $482.5 \pm 62.73$ & 0.902 & $500 \pm 78.74$ & $481.25 \pm 75.30$ & 0.860 \\
\hline & $\begin{array}{l}\text { After } \\
\text { exercise }\end{array}$ & $507.5 \pm 85.48$ & $502.5 \pm 81.02$ & 0.947 & $491.25 \pm 66.00$ & $485 \pm 72.90$ & 0.921 \\
\hline
\end{tabular}

As shown in Table 3, there was significant difference (p $<0.001$ ) found between mean heart rate before and after drug C (Celiprolol) before exercise in both the test (SL test and HGD test) and also significant difference found in mean systolic blood pressure in SL test before exercise ( $p$ $<0.05)$. There was no significance of difference $(\mathrm{p}>0.05)$ 
found in both the tests between mean heart rate, between mean systolic blood pressure, between mean diastolic blood pressure and mean PEFR before and after drug after exercise.

On carrying out among the group comparison using unpaired t test, no significant difference was found between the drug groups $(\mathrm{p}>0.05)$ for the parameters like heart rate, systolic and diastolic BP and peak expiratory flow rate. No adverse effects were reported in the study participants.

\section{DISCUSSION}

Beta blockers are known to improve exercise tolerance of the individual by its sympathetic blocking activity. Improvement in the exercise tolerance is important parameter in improving quality of life of the patients with cardiovascular diseases. Various beta blockers are available in market with huge variations in the cost. This study was aimed at evaluating and comparing the effects of various beta blockers on cardiovascular parameters after exercise.

The adrenoceptor blocking activity of any drug is more likely to be seen when sympathetic stimulation is provoked. Exercise is an appropriate physiological means of increasing cardiac sympathetic stimulation. ${ }^{10}$ As per present study there was no significance of difference ( $p$ $<0.05$ ) found in both the tests between mean heart rate, between mean systolic blood pressure, between mean diastolic blood pressure and mean PEFR before and after drug after exercise. Results were similar to the one of the study shown that the differences between the intrinsic heart rate effects of propranolol both at rest and on exercise are not significant. ${ }^{11}$ Compered to propranolol, atenolol is $\beta 1$ selective antagonist without intrinsic sympathomimatic properties but in this study it has shown no significant difference in PEFR. Celiprolol is a third-generation cardioselective $\beta$-receptor antagonist. It has low lipid solubility and possesses weak vasodilating and bronchodilating effects due to partial selective $\beta 2$ agonist activity6.Celiprolol in 40 to $100 \mathrm{mg} /$ day dose has been reported to promote NO production, and to inhibit oxidative stress. ${ }^{12}$ In one of the study, celiprolol had no effect on heart rate while propranolol caused a significant reduction compared with placebo. ${ }^{13}$ In this study all three drug produce reduction in heart rate before exercise. A study by Bush et al, showed that maximal expiration flow at $50 \%$ vital airway was significantly lower after Propranolol compared to celiprolol while in this study, no change in PEFR was seen. ${ }^{14}$ Studies support the idea that celiprolol reduces arteriolar resistance and improves blood flow without depressing cardiac function. ${ }^{15}$ In healthy adults, a single $400 \mathrm{mg}$ oral dose reduced standing diastolic blood pressure by approximately $10 \%$ with no change in systolic blood pressure. ${ }^{16}$ Here in this study change in systolic blood pressure with celiprolol was seen in the SL test. As only single dose of drug was given in present study there were no side effects observed during study period.

\section{CONCLUSION}

In conclusion, all the three drugs are effective in attenuating cardiovascular changes after sympathetic stimulation like exercise and there was no significant difference among them. $\beta$-adrenoceptor blocking drugs produce little or no slowing of resting heart rate but greatly reduce that during strenuous exercise. There was no significance of difference found between mean PEFR in both the tests for all three drugs suggesting equal effect on the respiratory parameter. Such comparative studies help in identifying the individual drugs' effect on different parameters and help in drug selection for the given patient. All cardiovascular disease like hypertension, ischemic heart disease requires tailored made approach for the patients considering their co-morbid conditions like asthma, diabetes etc so that overall quality of the life of the individual can be improved.

Funding: No funding sources

Conflict of interest: None declared

Ethical approval: The study was approved by the Institutional Ethics Committee

\section{REFERENCES}

1. Golan DE, Tashjian AH, Armstrong EJ, Armstrong AW. Principles of pharmacology: The pathophysiologic basis of drug therapy. 2nd ed. Lippincott Williams \& Wilkins; 2007.

2. Rang HP, Dale MM, Ritter JM, Flower RJ, Henderson G. Rang and Dale's Pharmacology. 7th ed. Elsevier: Churchill Livingstone; 2011.

3. Tripathi KD. Essentials of medical pharmacology. 6th ed. New Delhi: Jaypee Brothers; 2009:119.

4. Lopez SJ, Swedberg K, McMurray J. Expert consensus document on $\beta$-adrenergic receptor blockers. Eur Heart J. 2004;25:1341-62.

5. Chobanian AV, Bakris GL, Black HR. Seventh report of the Joint National Committee on prevention, detection, evaluation, and treatment of high blood pressure. J of Hypertension. 2003;42(6):1206-52.

6. Brunton LL, Chabner BA, Knollmann BC. Goodman and Gilman's The pharmacological basis of therapeutics. 12th ed. New York (NY): The McGrawHill Companies; 2010:176.

7. Benson MK, Berrill WT, Sterling GM, Decalmer PB, Chatterjee SS, Croxson RS, et al. Cardioselective and non-cardioselective beta-blockers in reversible obstructive airways disease. Postgrad Med J. 1977;53:143.

8. MERIT-HF Study Group. Effect of metoprolol CR $\mathrm{XL}$ in chronic heart failure: metoprolol $\mathrm{CR} / \mathrm{XL}$ randomised intervention Trial in congestive heart failure (MERIT-HF). Lancet. 1999;353:2001-7

9. Medhi B, Prakash A. Practical manual of experimental and clinical pharmacology. 1st ed. New Delhi (IN): Jaypee brothers; 2010:256-61. 
10. Chamberlain DA, Turner P, Sneddon JM. Effects of atropine on heart-rate in healthy man. Lancet. 1967;290(7505):12-5

11. Carruthers SG, Shanks RG, McDevitt DG. Intrinsic heart rate on exercise and the measurement of $\beta$ adrenoceptor blockade. Br J Clin Pharmacol. 1976 Dec;3(6):991-9.

12. Gupta S, Wright HM. Nebivolol: A highly selective $\beta 1$-adrenergic receptor blocker that causes vasodilation by increasing nitric oxide. Cardiovasc Therapeut. 2008;26(3):189-202.

13. Busst CM, Bush A. Comparison of the cardiovascular and pulmonary effects of oral celiprolol, propranolol and placebo in normal volunteers. $\mathrm{Br} \mathrm{J}$ Clin Pharmacol. 1989 Apr;27(4):405-10.

14. Pittner H. Pharmacodynamic actions of celiprolol, a cardioselective beta-receptor blocker. Drug Res. 1983;33(1 A):13-25.
15. Louis WJ, Drummer OH, Fung LH. Pharmacology of celiprolol. Cardiovasc Drugs Therapy. 1990;4:1281-6.

16. Milne RJ, Buckley MM. Celiprolol. An updated review of its pharmacodynamics and pharmacokinetic properties, and therapeutic efficacy in cardiovascular disease. Drugs. 1991;41(6):941-69.

Cite this article as: Patel SP, Shah RB. Study of effect of propranolol, atenolol and celiprolol on exercise induced changes in heart rate, blood pressure and peak expiratory flow rate in healthy human volunteers. Int J Basic Clin Pharmacol 2019;8:950-5. 